\title{
ADMINISTRATION AND ENFORCEMENT
}

\section{Bernard G. Segal $†$ and Edward W. Mullinix $\ddagger$}

Characterized as it is by litigation of far greater than average length and complexity, the antitrust field is one in which matters of procedure assume unusual importance. Every experienced antitrust lawyer knows that a case can be, and often is, won or lost long before trial, either through settlements impelled by full development of the facts in discovery proceedings or through advantages gained or lost in the interplay of a host of less tangible factors generated by the procedural framework within which the litigation progresses.

Chapter VIII, the concluding chapter of the Report of the Attorney General's National Committee To Study the Antitrust Laws, is devoted to the subject of Administration and Enforcement. ${ }^{1}$ Within this broad rubric, the Committee directed its attention to a series of specific problems. These problems, and the Committee's recommendations for their solution, vitally affect the government official and attorney on the one hand and the private practitioner on the other.

It is our purpose to explore these effects, particularly from the viewpoint of the practicing lawyer, to expand some of the problems necessarily dealt with in capsule form in a report of such comprehensive scope, and to present some guides to specific application of the Report's general recommendations. We shall organize our discussion under the same topical headings used in the Administration and Enforcement chapter.

By way of introduction, we note the broad procedural framework within which the antitrust laws are enforced. The Sherman Act carries criminal sanctions, to be imposed by the federal courts at the suit of the Attorney General. ${ }^{2}$ The Clayton Act, on the other hand, carries no criminal sanction, except under section 2 , as amended by the Robinsin-Patman Act, providing criminal penalties for certain discriminatory practices. ${ }^{3}$ But the Sherman Act and the Clayton Act both provide

$\div$ Member of the Philadelphia Bar. Member, Attorney General's National Committee To Study the Antitrust Laws.

$\neq$ Member of the Philadelphia Bar.

1. Report of the Attorney General's National Committee to Study the ANTITRUST LAwS 343-88 (1955) (hereinafter cited as REPORT).

2. Sections 1, 2, 3, 26 STAT. 209 (1890), 15 U.S.C. $\S \S 1,2,3$ (1952), as amended, Pub. L. No. 135, 84th Cong., 1st Sess. (July 7, 1955).

3. 49 STAT. 1528 (1936), 15 U.S.C. $\$ 13 a$ (1952). There has never been a conviction under this section. See the discussion in the REPORT at 198-201. 
for civil enforcement by the federal courts at the suit of the Attorney General for injunctive relief; ${ }^{4}$ and a new section $4 \mathrm{~A}$ of the Clayton Act, just adopted ${ }^{5}$ in conformity with a recommendation of the Committee, ${ }^{6}$ gives the United States the right to sue (for single damages only) for injury to its proprietary interests when they are injured by violation of the antitrust laws. This right had been denied under prior case law. ${ }^{7}$ There is likewise governmental enforcement through orders issued by the Federal Trade Commission (1) under an express statutory provision insofar as the Clayton Act is concerned ${ }^{8}$ and (2) under case law ${ }^{9}$ holding that a Federal Trade Commission order may reach conduct tending to restrain trade, as an unfair method of competition under section 5 of the Federal Trade Commission Act, ${ }^{10}$ even though the same conduct might also violate the Sherman Act. Finally, there is enforcement through suits by private parties in the federal courts for treble damages or injunctive relief in cases of violation of either the Sherman or the Clayton Act. ${ }^{11}$

The practicing lawyer, therefore, may find himself representing a defendant in a civil or a criminal proceeding instituted by the Department of Justice, a respondent in a proceeding brought by the Federal Trade Commission, or either a plaintiff or a defendant in a private action for treble damages or injunction or both.

\section{The Department of Justice}

\section{Antitrust Investigations}

Factual investigation necessarily precedes formal action, whether civil or criminal, by the Antitrust Division of the Department of Jus-

4. Sherman Act § 4, 26 STAT. 209 (1890), as amended, 15 U.S.C. $\$ 4$ (1952); Clayton Act § 15, 38 STAT. 736 (1914), 15 U.S.C. § 25 (1952).

5. Pub. L. No. 137, 84th Cong., 1st Sess. (July 7, 1955).

6. REPORT at 385 .

7. United States v. Cooper Corp., 312 U.S. 600 (1941). States and municipalities have always been able to maintain suits on their own behalf, Georgia v. Evans, 316 U.S. 159 (1942); Chattanooga Foundry v. Atlanta, 203 U.S. 390 (1906), but not on behalf of private persons, Oklahoma ex rel. Phillips v. American Book Co., 144 F.2d 585 (10th Cir. 1944).

8. Section 11, 38 Stat. 734 (1914), as amended, 15 U.S.C. $\$ 21$ (1952).

9. See, e.g., FTC v. Cement Institute, 333 U.S. 683, 693 (1948).

10. 38 Stat. 719 (1914), as amended, 15 U.S.C. $\$ 45$ (1952).

11. Clayton Act $\$ \$ 4,16,38$ STAT. 731, 737 (1914), 15 U.S.C. $\$ 15,26$ (1952), as amended, Pub. L. No. 137, 84th Cong., 1st Sess. (July 7, 1955). There is an area of doubt, however, as to the existence of a private right of action under the criminal provision of the Robinson-Patman Act. See note 3 supra. Some courts have declined to regard this section as one of the "antitrust laws" for the violation of which a private right of action is created by the Clayton Act. E.g., National Used Car Market Report, Inc. v. National Automobile Dealers Ass'n, 108 F. Supp. 692 (D.D.C. 1951), aff'd, 200 F.2d 359 (D.C. Cir. 1952). Contra, Balian Ice Cream Co. v. Arden Farms Co., 94 F. Supp. 796 (S.D. Cal. 1950). 
tice. The Report finds that presently available procedures are adequate, through the use of grand jury compulsory process, to obtain both documentary and testimonial evidence in criminal proceedings. ${ }^{12}$ In a civil matter, on the other hand, the Department must depend upon voluntary cooperation, use of discovery proceedings after a civil complaint has been filed, or resort to a grand jury investigation. ${ }^{13}$ These procedures are deemed inadequate because: (1) voluntary compliance is not always forthcoming; (2) there is obvious impropriety in the practice of filing a skeleton complaint in the hope that facts to support it may be developed through discovery; and (3) it is inappropriate to resort to a grand jury investigation when a civil proceeding is contemplated from the outset. ${ }^{14}$

On these findings, the Committee has based its controversial recommendation for the Civil Investigative Demand, which has been substantially embodied in a bill now pending in Congress. ${ }^{15}$ Under the Report's recommendation, the Attorney General would be authorized, in a civil antitrust investigation, to issue a Civil Investigative Demand upon any corporation, partnership or association, requiring the production of correspondence and other business records, not privileged, relevant to particular antitrust offenses stated to be under investigation. Enforcement of the demand could be obtained by the Attorney General through the district court in which the recipient maintains its principal place of business, and, on the other hand, relief from such demand could be secured from this court on a showing that the demand is unreasonable, seeks documents irrelevant to the offenses stated to be under investigation, or fails adequately to describe the material required to be produced. ${ }^{16}$ The Report contemplates that the Attorney General would resort to use of the formal demand where requests for voluntary production of documentary evidence would probably be ineffective and that use of the demand would end the necessity for resorting to grand jury proceedings in a civil investigation. ${ }^{\mathbf{1 7}}$

The bill now pending in Congress differs from the Report's recommendation in some significant respects. Whereas the Committee would have required that the particular offense under investigation be stated, the proposed legislation requires nothing more than iden-

12. REPORT at 344.

13. Ibid.

14. Id. at $344-45$.

15. H.R. 7309, 84th Cong., 1st Sess. (1955). The bill, introduced by Congressman Celler on July 13, 1955, at the request of the Attorney General, is now before the House Judiciary Committee. It follows substantially the Report's recommendation. Significant divergences are pointed out below.

16. REPORT at 346 .

17. Id. at 347. 
tification of the statute involved and, "where feasible," the particular section. Such statutory identification would be so broad as to be meaningless. A court faced with a problem of relevancy would be in a much better position effectively to control use of this process if the Department were required to particularize the offense under investigation. The other important divergence from the Committee's recommendation is that the bill would permit use of the demand upon any person, rather than limiting its use to corporations, partnerships and associations, as the Committee recommended. The broader provisions of the bill are an unnecessary invitation to more-aggravated problems under the fifth amendment. Finally, the venue provisions of the bill in its present form are not properly drafted. ${ }^{18}$

Controversy, from both directions, has attended the Civil Investigative Demand recommendation. On the one hand, it is argued that there is really no need to give such power to the Attorney General, because not more than ten per cent of those who are asked to submit data voluntarily refuse to cooperate; the creation of such power is opposed as an undesirable enlargement of executive authority inconsistent with the basic distinction between the executive and the judiciary. ${ }^{19}$ On the other hand, it is argued that limitation of the procedure to documentary, as distinguished from testimonial, evidence renders it ineffective; that there is nothing inappropriate in use of a grand jury for investigation in this kind of matter, but since the Civil Investigative Demand is not proposed as a supplement to existing procedures, the recommendation must be regarded as ". . . a step to curtail the Department's most effective investigative device,"-the grand jury investigation. ${ }^{20}$

Both views were, of course, vigorously debated in the Committee. In voting to reject them and to recommend adoption of this new investigative device, the Committee was of the view that if, as it believed, this procedure would greatly facilitate investigations by the Department in civil cases, then despite the fact that subsequent criminal proceedings would not be barred where a Civil Investigative Demand had been used-and indeed the documents so obtained could be submitted to a grand jury-nevertheless, the eventual result would be the use of grand jury investigations only in cases where criminal prosecu-

18. Section 5(b) permits the recipient of a Demand to seek relief from the district court "where the petition [for enforcement by the Government] under Section 5(a) was filed." H.R. 7309, 84th Cong., 1st Sess. §5(b) (1955). Since a petition for enforcement is not intended to be and should not be a condition to the seeking of relief by a recipient, there should be independent ventue provisions for that purpose.

19. REPORT at 348 .

20. Id. at $348-49$. 
tion is contemplated. As to the fear of enlargement of executive power, it was felt that the judicial review provided is an adequate safeguard against abuse of authority by an Attorney General. ${ }^{21}$

More important, regardless of the adoption or nonadoption of the Committee's recommendation, is the attitude of the antitrust bar toward voluntary compliance with the Department's investigative requests. There is, of course, a natural reluctance to volunteer evidence to a prosecutor, particularly since rights under the fourth and fifth amendments may be waived. ${ }^{22}$ Nevertheless, it is our view that, generally, the practicing lawyer should follow the practice of voluntary compliance and cooperation.

The fact that the ordinary investigation, if allowed to run its own course, provides no contact between the private party or his counsel and anyone other than agents of the Federal Bureau of Investigation who simply examine documents or records in accordance with instructions from the Antitrust Division should be no deterrent to such cooperation. In our experience, the attorneys of the Antitrust Division, both at Washington and in the field, are readily available to counsel for parties under investigation when counsel seek conferences with them.

An atmosphere of voluntary compliance and cooperation permits the possibility of informal negotiation with Antitrust Division lawyers which can be exceedingly valuable in the opportunities it presents for the explanation of equivocal facts and eradication of the prosecutor's adverse conclusions based on incomplete facts and one-sided presentations by private complainants to the Antitrust Division. If a full, factual disclosure at this preliminary stage convinces the Antitrust Division that there has been no offense, the client will have been saved from an immensely expensive piece of litigation and, in all likelihood, from the adverse publicity normally accompanying any indictment or formal complaint by the Department of Justice. Finally, those of us who, as a matter of principle, oppose use of grand jury procedures in a civil matter and would prefer to spare our clients the necessity and embarrassment of appearance before a grand jury in an investigation of their activities have no one but ourselves to blame if our refusal of voluntary cooperation results in use of a grand jury subpoena by the Department.

21. Mr. Segal, as a member of the Committee, joined in the majority's conclusions and recommendations. Thus, as the Report itself explains, he is in substantial agreement with the Report's basic analysis and conclusions but does not necessarily assume responsibility "for each phrasing of each case or shade of reasoning." REPORT at 5 .

22. For further discussion of this entire problem, see Nitschke, Procedure in Antitrust Investigations, 1950 U. InL. L. ForUa 593, 597, 600. 


\section{The Decision To Proceed}

In this section, the Report deals with the internal function of the Antitrust Division, after investigation is completed, in determining whether to proceed at all, whether to proceed civilly or criminally, or both, and what relief to demand. ${ }^{23}$

It is of particular importance to the practicing lawyer to recognize that the Antitrust Division makes a conscious choice between civil and criminal litigation in any given case. As reported to the Committee, the present policy of the Antitrust Division is to proceed criminally where the case involves price fixing, any other violation of the Sherman Act where there is proof of a specific intent to violate the act, predatory practices such as boycotts, or a second violation of the antitrust laws by a previously convicted defendant. These are not hard and fast rules. Other factors may be taken into account, e.g., the defendant's knowledge that practices similar to his own have been held violative of the Sherman Act in a prior civil suit against other persons.

Once the Antitrust Division decides to proceed criminally, it may decide to file a civil suit as well if the situation is one in which the Division believes that effective injunctive relief can be obtained. However, it avoids bringing civil actions against price fixing because any injunction obtained would add nothing to the proscriptions already contained in the Sherman Act.

The decision to bring a criminal action is reviewed at a number of levels within the Antitrust Division. If the attorney in charge of the investigation is in the field, his recommendation is reviewed by the field office chief, then by the appropriate litigation section chief in Washington, next by the first or second assistant to the Assistant Attorney General in charge of the Antitrust Division, and finally by the Assistant Attorney General himself. ${ }^{24}$

The Committee found itself in general accord with this present policy but emphasized its desire for a policy of limitation, confining use of the criminal process to instances ". . . where proof of violation is

23. The question of relief is treated in two aspects: the amount of criminal fines for Sherman Act violations and the criteria which should govern demands for dissolution, divorcement or divestiture in government equity cases. The subject of dissolution, divorcement, and divestiture is treated rather fully in REPORT at 353-58; to elaborate at all upon it, and to appraise and discuss the basic differences of viewpoint, legal, economic and social, expressed in the Report would require an article devoted to this subject exclusively. As to criminal fines, the Committee's recommendation for an increase has already been implemented by. Pub. L. No. 135, 84th Cong., 1st Sess. (July 7, 1955), increasing the previous $\$ 5,000$ maximum fine to $\$ 50,000$ rather than the $\$ 10,000$ recommended by the Committee. REPORT at 352 .

24. Reporr at 350. 
clear and the law is settled" not only as to the illegality of the practices involved but also as to antitrust coverage in the field in question. ${ }^{25}$

Based on this approach to the choice between civil and criminal proceedings, the Committee rejected any proposal to prescribe by statute the line of demarcation between violations to be attacked civilly and those to be attacked criminally. ${ }^{26}$

With an awareness of these policies followed by the Antitrust Division, counsel is in position, if he engages in informal discussions with the Antitrust Division, to argue in the appropriate case for a civil rather than a criminal action. Closely related is the matter of possible advance agreement on a nolo contendere plea to a criminal indictment or for entry of a consent decree in a civil suit. Such a course merits careful consideration at this early stage, because apart from factors like the expense, publicity and other effects of a trial, a conviction or a litigated decree in favor of the Government becomes available to private treble damage plaintiffs as prima facie evidence under section 5 of the Clayton Act ${ }^{27}$ and thus opens the way to liabilities which may far transcend the importance of not being on the losing end of a government case. It should be noted also in this connection that, again by virtue of section 5 of the Clayton Act, the statute of limitations applicable to a plaintiff's treble damage action is tolled during the pendency of a government proceeding against the same defendant, and a protracted government proceeding can therefore leave a defendant vulnerable to treble damage suits involving damage periods covering many years. ${ }^{28}$

25. Id. at 351. Thus, for example, the Committee deemed it improper for the Government to proceed criminally in United States v. Southeastern Underwriters Ass'n, 322 U.S. 533 (1944), where the defendants had relied on the inapplicability of the antitrust laws to premium rates on fire insurance. In somewhat the same vein, the Report points out that a second offense does not necessarily warrant indictment except where it is substantially the same as the first. REPORT at 351.

26. Ibid.

27. 38 Stat. 731 (1914), 15 U.S.C. $\$ 16$ (1952), as amended, Pub. L. No. 137, 84th Cong., 1st Sess. \&2 (July 7, 1955).

28. Under the holdings of some courts, the suit of United States v. Paramount Pictures, Inc., Equity No. 87-273, S.D.N.Y., July 20, 1938, was pending from 1938 to 1950 . E.g., Twentieth Century-Fox Film Corp. v. Brookside Theatre Corp., 194 F.2d 846 (8th Cir.), cert. denied, 343 U.S. 942 (1952). Contra, Barnett v. Warner Bros. Pictures Distributing Corp., 112 F. Supp. 5 (N.D. Ill. 1953). The Burnett interpretation is proper because a consent decree had been entered in the Paramount case in 1940 and continued in effect until 1944 when the Government moved to modify the decree to seek divorcement and divestiture and the case was then brought on for trial. 194 F.2d at 857. Under the extreme holding of the Twentieth Century-Fox case, and assuming the applicable statute of limitations to be four years, there is the possibility of a treble damage suit involving a damage period of sixteen years. This is expensive not only in terms of the potential recovery but also from the standpoint of litigation cost. The Report's recommendation for a federal statute of limitations to govern antitrust cases was designed to prevent such a result by providing that any private plaintiff who relies on the tolling provision of section 5 of the Clayton Act would be limited to a four-year damage period but could, at his election, recover 


\section{Review Procedure Within the Antitrust Division}

Somewhat akin to the kind of preliminary discussion and exchange of views to which we have referred above is the Committee's recommendation for a review group within the Antitrust Division.

Recognizing that decisions made within the Division merit careful analysis of economic, marketing and business problems, and that such analysis can best be made". . . in an atmosphere not dominated by a zealous prosecutor bent solely on court success," the Report suggests establishment by the Assistant Attorney General in charge of the Antitrust Division of ad hoc or continuing groups of staff lawyers and economists having no prosecuting responsibilities. ${ }^{29}$ Such groups would review any matter submitted by the Assistant Attorney General either on his own initiative or in response to the request of a potential or actual defendant. While the Committee suggests no set procedure, it indicates that a review group could render advice-not bindingas to the choice between civil and criminal proceedings, as to the relief to be sought in civil proceedings, and in connection with the negotiation of consent judgments.

This suggestion is frankly advanced as an experiment. It may be that the dissenting members of the Committee are correct in feeling that such procedures would be cumbersome and unduly wasteful since the same functions are now performed by the Assistant Attorney General and his first or second assistant..$^{30}$ It may also be, as argued in another dissent, that creation of the review groups would be ". . . to encumber the exercise of the prosecutor's discretion with novel internal administrative reviews on request of a defendant. . . ." 81

Nevertheless, we should like to see the experiment made. It can work, we feel, with intelligent administration and staunch resistance by the Assistant Attorney General to misuse engendered by inexperienced defense counsel or attempts to prostitute the process for purposes of delay. With a strong Assistant Attorney General in charge, this would seem to be an excellent time to institute the experiment.

The review group proposal is particularly intriguing because of the possibility it offers defense counsel for discussion or negotiation with the Antitrust Division in an atmosphere free of an enforcement official's zeal and his preconceived, however justified, notions of the case. While such discussions or negotiations even in an attenuated

damages accruing during any consecutive four-year period not otherwise barred. REPORT at 384. For further discussion of the statute of limitations recommendation and its legislative implementation, see pp. 308-10 infra.

29. REPORT at 358-59.

30. Id. at 359 .

31. Id. at 388 . 
atmosphere are desirable in our judgment, it is obvious that they will be much more likely to be productive if they are participated in by nonprosecuting representatives of the Antitrust Division whose motives and attitudes will be less likely to engender fear and suspicion in defense counsel or their clients. ${ }^{32}$

To a very substantial degree, antitrust defense lawyers will hold the key to success or failure of the review group experiment if it is undertaken by the Antitrust Division. Recognizing the considerations underlying the proposal and the benefits to be gained from success of the experiment, counsel for private parties can do a good deal to ensure success of the experiment and attainment of the hoped for benefits.

\section{Consent Settlement Procedures}

The Report considers five aspects of consent settlement procedures within the Antitrust Division. This treatment is of significance to the practicing lawyer in terms of the insight into Antitrust Division procedures which he should have before entering into negotiations with representatives of the Division.

\section{Prefiling Negotiation}

The Report notes former policy of the Division in refusing to negotiate with defendants prior to the filing of a formal complaint. This practice, based on a feeling that a complaint crystallizes the issues and thus expedites settlement, and on a fear that potential defendants would use negotiations as a delaying device if they were undertaken prior to the filing of a complaint, has been relaxed recently, and the Department is experimenting with prefiling negotiations. ${ }^{33}$ The Report's endorsement of the practice of prefiling negotiations augurs well for their continuance.

Defense counsel who learn that an investigation is under way should give careful consideration to seeking settlement negotiations at the earliest possible time. Assuming that a settlement is desirable from the defense standpoint, the earlier it comes the better, not only because the publicity attendant upon entry of a consent decree is likely to be less unfavorable than the publicity attendant upon the filing of a con-

32. "As any advocate preparing for a legal bout, the antitrust attorney seizes whatever is helpful, discards whatever might tell against him, draws items together into a purposive picture. He gathers evidence instead of finding facts; pieces together a conspiracy rather than dissects trade practice. The grand total at which he arrives is far more a recitation of wrongdoing than a picture of an industry at work." TNEC Monogrape No. 16 at 33 (1940).

33. REPORT at 360 . 
tested proceeding, but also because, as we indicated above, early negotiation furnishes defense counsel with a better opportunity to present his position in an atmosphere unprejudiced by the effects of conceptions publicly expressed and positions publicly taken by the prosecutor.

One Committee member dissented from the endorsement of prefiling negotiations on the ground that it would ". . . whittle away the last remnants of judicial control and public scrutiny in this area. . . ." He argues that ". . . the settlement of an antitrust case ought not to be a simple matter of bargaining between the Department and the defendant." 34

It seems to us the question is one of weighing the interests involved. It is well known that the Antitrust Division has for many years operated under the handicaps of insufficient appropriations and, consequently, inadequate personnel. It must constantly select the investigations to institute and the suits to file on the basis of available resources and manpower. Early settlement of one case, even though on terms not so drastic as the best that could be hoped for in a decree won only after years of litigation, leaves the Division free to commence other investigations and file other suits. Certainly, the officials of the Division, charged with the overall responsibility for enforcement of the antitrust laws, are in the best position to decide when the public interest is served by an expediting procedure in a particular case. Who better than they are to be entrusted with such determinations? Certainly not the courts, for necessarily this is an executive function. The - fears of lack of judicial control and absence of public scrutiny would appear to be unfounded. Courts normally approve consent decrees in government instituted antitrust cases without change, relying upon the same executive responsibility of the Department of Justice which constitutes the justification for the Committee's recommendation in the first place. Necessarily, the settlement of an antitrust suit is practically always, and at any stage, what the dissent seems to fear it will become under prefiling negotiation procedures, a "matter of bargaining between the Department and the defendant."

There is nothing in the Committee's suggestion which eliminates publicity of the consent decree eventuating after prefiling negotiations; and we suggest that the "public scrutiny" is not very significant in influencing the course of the proceeding or the wording of a decree.

Negotiation with Less Than All Defendants

Next, the Committee notes that current practice in the Antitrust Division is to negotiate consent settlements with fewer than all of the 
defendants in the case. ${ }^{35}$ This practice, approved by the Committee, presents one danger: a defendant who settles may find, sometime later, that after litigation his original codefendants have convinced the court to enter less severe relief against them, or no relief at all. To remedy any such inequity, the Report recommends that the Department of Justice should, in appropriate cases, ask the court to square the consent judgment with the litigated decree. ${ }^{36}$ Without indicating comprehensive guides for the situations in which this should be done, the Report suggests, as one example, the case where the litigated judgment was based on a substantive rule of law applicable to all defendants, or where dissimilar judgments would prejudice effective competition. ${ }^{37}$

This is not to say that there will not still be potential difficulties which must be taken into cognizance by defense counsel who are negotiating a settlement in behalf of less than all the defendants involved in the case. Possible disadvantages to the consenting defendants must be taken into consideration in appraising the desirability of entering into a consent decree, for absent the Division's willingness to seek a modification of a consent decree, the defendants will have little chance to obtain a modification on their own motion, unless they can convince the court that the entry of a different form of contested decree has created such a change of circumstances in the industry as to render it equitable for the court to modify the consent decree. ${ }^{38}$

\section{Negotiations with Trial Staff}

One aspect of the Antitrust Division's current practice, deemed undesirable by the Committee, is the subject of an affirmative recommendation for change. The Department now requires that consent negotiations be conducted in the first instance with the trial staff assigned to the case. If agreement is reached, the judgment section must then review it, and further negotiations with the members of that staff will be necessary if they disagree, as is often the case, with the conclusions of the trial staff. Since the Committee regarded this as involving an unnecessary duplication of effort both by government personnel and defense counsel, the Report recommends that the Division attempt to avoid such waste by some internal procedure aimed at crystallizing the Government's position before negotiations begin, thus minimizing renewed and separate negotiation. ${ }^{39}$

35. Ibid.

36. Id. at $360-61$.

37. Id. at 361 .

38. United States v. Swift \& Co., 286 U.S. 106 (1932). See also United States v. RCA, 46 F. Supp. 654 (D. Del. 1942).

39. REPORT at 361 . 


\section{Drafting of Consent Decree}

Another affirmative recommendation made by the Report is one of which experienced defense counsel may not always want to take advantage. The present practice of the Antitrust Division is to require defendants to submit the initial draft of a consent judgment. Recognizing that this may impose an unnecessary burden on a defendant who has had no experience with antitrust matters or who cannot determine from the complaint the relief which the Government considers necessary, the Report recommends that the Antitrust Division submit the initial draft if the defendants, in good faith, so request. ${ }^{40}$ Experienced counsel, however, will find occasions when it is desirable to prepare the initial draft themselves, in order that it may embody a more complete expression of their own views and approach as the basis for further negotiation. This is sometimes more effective than the alternative of picking away at a draft prepared by government attorneys.

\section{Limiting Scope of Consent Decree}

In its final recommendation concerning consent procedures, the Report urges that the Antitrust Division ". . . should not seek relief (1) deemed by the Supreme Court to transgress constitutional boundaries; or (2) which, in the particular case, could not reasonably be expected after litigation." 41

We believe that the dissent of one member of the Committee misconstrues the Report's recommendation when it charges that "it is the close questions of constitutionality that the Majority Report asks the Government 'not to press in consent negotiations.' " 42 The Report itself makes this clear. Rejecting the argument that the Division should demand whatever relief its bargaining position can coerce in the public interest, the Committee took the view that there is a responsibility resting on the prosecutor to stay within lawful bounds. ${ }^{43}$ Thus, the Report strikes at past practice of the Antitrust Division in seeking consent decree provisions, for example, requiring royalty-free licensing of patents, a remedy refused in the Hartford-Empire case, ${ }^{44}$ and requiring defendants to submit written reports in connection with enforcement of a judgment, contrary to the Bausch \& Lomb holding. ${ }^{45}$

40. Ibid.

41. Ibid.

42. Ibid.

43. Ibid.

44. Hartford-Empire Co. v. United States, 323 U.S. 386, 413-18 (1945).

45. United States v. Bausch \& Lomb Optical Co., 321 U.S. 707, 724-28 (1944). 
The entire question of consent settlement presents problems as to which generalizations are difficult and apt to be deceptive. A form of relief held to be inappropriate under one set of facts may be entirely appropriate in a factual situation seemingly only slightly different. The important thing from the standpoint of defense counsel is an awareness of the problem and of the considerations bearing on it. .

Counsel approaching negotiations with the Antitrust Division must recognize that his bargaining position is almost inevitably inferior to the Division's. It is an unfortunate circumstance that government officials, whether in the Antitrust Division or elsewhere, are often not disposed to take the attitude, prevailing in private litigation, that a settlement avoids the uncertain risks of litigation and that each party should therefore give up something in order to avoid the risk that a court will ultimately say he is entitled to nothing. This attitude stems in part, perhaps, from a feeling that the Government is in a position different from that of a private litigant and must not compromise the public interest; in part from what we believe to be the specious belief that failure to insist on abandonment of certain practices constitutes outright approval of them; and in part from insufficient consideration of the factor of expense to the Government which will be involved in all-out litigation of issues which could be compromised if the Government were willing to relax its position. In the relatively uncomplicated case, therefore, the position of the Government may well be one of "take it or leave it," and even in the more complicated case where there is room for some give and take, the Government is usually in the position of doing most of the taking and very little of the giving.

There are at best only a few intangible factors which may induce a prosecutor to relax his position. Where he has a weak case, he may fear that the outcome after litigation will mar his personal record as a prosecutor. As we have already noted, the prospect of litigation rather than settlement may be an important one to the Government if its manpower and other resources are overtaxed at the time when a settlement is under consideration, conditions acutely present at this time. But as against these, defense counsel must realize that often his own desire or need for a settlement is greater because: (1) the factor of litigation expense will normally be a much more important one to his client than to the Government; (2) his client may have a very substantial interest in avoiding too great and continuing adverse publicity; and (3) the particular circumstances may be such that it is important not to create a magnet for treble damage suits so often precipitated by an antitrust judgment in favor of the Government. 


\section{Trial Problems}

The complexity of antitrust issues creates extraordinary problems in the handling of trials and of pretrial discovery. Out of the almost countless number of matters in this connection which have received attention in recent years, the Report has singled out only four specific issues for treatment. ${ }^{46}$

Although the Report treats these problems as a part of its discussion of the role of the Department of Justice in antitrust administration and enforcement, the same problems prevail in private litigation under the antitrust laws, and the Report's treatment of them is expressly in terms of both government and private actions.

\section{Single Judge}

First, noting the practice in some federal districts of assigning each antitrust case to one judge for all purposes, the Committee recommends adoption of this practice in all districts. The recommendation is based on the obvious desirability of (1) saving the time involved when more than one judge must become familiar with the complexities of a protracted case and (2) creating in a single judge a perspective of the entire litigation which he can bring to bear upon each separate matter coming before the court as the case progresses through preliminary motions, discovery motions, pretrial conferences and, finally, the trial itself. ${ }^{47}$

These objectives are attained in the Eastern District of Pennsylvania, where this article is written, through a slight variation of the practice recommended by the Report. Although the procedure is not formalized in any written rule, the practice in the Eastern District in all cases, antitrust or otherwise-is that once there comes before a given judge any phase of a case through which the judge becomes familiar with matters going to the merits, then all subsequent proceedings in the case normally will go to that judge. In the event of his temporary unavailability, routine matters, particularly those where there is consent or no opposition, will generally be handled by the judge who happens to be presiding on the motion list.

This practice has worked well in all types of cases, including antitrust cases. The only difficulty it has engendered is one that will be encountered in any situation where a single judge must pass on everything which arises in a case. While matters where there is consent

46. For a more comprehensive treatment of the overall problem, see Judicral Conf. of the United States, Report on Procedure in Antitrust and Other ProTRACTED CASES (1951).

47. REPORT at 362 . 
or no opposition can be handled by another member of the court when the assigned judge is temporarily unavailable, contested matters of any significance at all must await availability of the assigned judge. A contested discovery motion, for example, under the practice in the Eastern District of Pennsylvania, must await a listing on one of the monthly argument lists on which the judge in charge of the case is sitting-unless speedy disposition of the matter is sufficiently important to induce the judge to agree to hear it specially, something which the bar is properly reluctant to ask a busy judge to do unless the urgency is compelling. This frequently means that a motion will be pending for as long as two or three months before it can be argued, and it has not been unusual in our experience to encounter even longer delays.

This disadvantage, of course, is far outweighed by the many advantages, from the standpoint of the court as well as the parties, inherent in the handling of the case by a single judge. Furthermore, we believe that, to a very substantial extent, some of the delay can be eliminated if both court and counsel attempt to develop a close working relationship in controlling the progress of the case. Periodic conferences among the court and counsel for the purpose of surveying the issues pending for decision and planning their disposition would usually be helpful, particularly in the so-called "big case."

\section{Defining the Issues}

The Report next considers the question: how can issues best be particularized and pretrial discovery most effectively used? The Committee finds that there has been, in the past, insufficient particularity of the issues to be tried in antitrust cases, with the result that, under the Federal Rules of Civil Procedure, there is no effective limit on the scope of discovery, with the result that, as the Report points out, the courts are turned into investigating agencies. The Committee notes a number of factors which have contributed to this problem: liberality in modern pleading; lack of adequate means for investigation of civil offenses before a government complaint is filed; and the reluctance of trial courts to resolve disputed issues of law in advance of trial or to compel the parties to particularize broad issues. ${ }^{48}$

The Committee's recommendations approach this problem in two stages.

First, in order to achieve a particularization of issues where the pleadings do not do so sufficiently, the Report suggests three possible procedures : a defense motion for a more definite statement and a liberal

48. Id. at $362-63$. 
construction of rule 12 (e) of the Federal Rules of Civil Procedure to require an antitrust plaintiff to state charges in full and with adequate particularity; pretrial conferences at which the court and parties would have before them a detailed statement of issues, initially prepared by the plaintiff, and at which the court might require a statement of the defense position as the conference proceeds; and written interrogatories framed to secure a statement of the issues of fact raised under the broad charges of the complaint or in an affirmative defense-as distinguished from interrogatories used to discover evidence. ${ }^{49}$

Second, with respect to discovery proceedings themselves, the Report suggests use of a procedure under which any party anticipating the use of any discovery process would, where feasible, be required by the court to submit a pretrial statement setting forth to the court's satisfaction the issues as to which discovery is sought. The statement, if approved by the court after hearing, would mark the permissible limits of such discovery unless modified for good cause. The Committee emphasizes that this recommendation should not limit any proper use of discovery but rather is designed to prevent abuses which have occurred when discovery is allowed to run its course without adequate court supervision. ${ }^{.0}$

The importance of reducing procedural complexities in antitrust litigation wherever possible cannot be over-emphasized. Extensive discovery is very expensive business, involving as it does considerable stenographic costs for depositions, sizable accountants' fees in many cases, and substantial legal fees incurred because of the large amount of counsel's time required not only for the conduct of his own client's discovery proceedings but also in connection with his opponent's. The factor of expense, therefore, can turn discovery into a weapon of oppression, used for the harassment of an impecunious party, and as an instrument of delay. Discovery may also be misused by a party seeking to subvert its processes to the development of information helpful for competitive purposes rather than for legitimate litigation objectives. Discovery may be misused when it takes the form of a campaign to take. the depositions of top corporate officers who know nothing about the case in the hope of coercing an unmerited settlement. Courts must be astute to guard against such abuses, under the protective order machinery of rule $30(\mathrm{~b})$ and through the use, where appropriate, of the devices suggested in the Committee's recommendations.

The Committee's proposals cannot be regarded as hard and fast

49. Id. at 363 .

50. Id. at 363-64. 
rules for indiscriminate application in every case. The approach must be on a practical level, guided by an appreciation of the legitimate purposes of discovery to uncover facts and crystallize an opponent's position. Since extensive discovery effectively eliminates the element of surprise at the trial, care must be taken in requiring an advance outline of the purposes of discovery in order that the outline does not serve as a coaching device for an important witness whom the parties should properly have at least one opportunity to cross-examine without his being rehearsed. On the other side of the coin are the practices of the party who attempts to obtain innumerable items to which he is really not entitled but who makes the attempt, usually through the medium of written interrogatories or motions for production of documents under rule 34 , in the hope that a busy judge will not listen to all of the opponent's sound but necessarily frequent objections and will, therefore, permit at least a few things to slip through. Courts should be alert to this device, should strike it down when its use is attempted, and should invoke vigorous methods to control such a party. In such a situation, the Committee's recommended pretrial statement could be of considerable help.

The necessity for formal measures to particularize issues and control discovery proceedings may become less imperative in the ordinary case if the Committee's one-judge recommendation is followed. Our experience in the Eastern District of Pennsylvania, where a one-judge system is already in effect, indicates that the problems of particularizing issues and controlling discovery are less troublesome than in other districts where matters arising at various stages of the case come before different members of the court. For example, it has frequently happened that either under a motion for a protective order pursuant to rule $30(\mathrm{~b})$, or in connection with objections to extensive interrogatories, the court's rulings have been such that they chart the course for substantially all of the later discovery proceedings in the case. Experienced, responsible counsel will follow this course because they know that the same judge is more likely to have the same opinion when a similar question is raised later than would be the case if a different judge were sitting. The judge, himself, can properly try to shape his rulings so that they will guide the course of future discovery, since he himself will be available to revise his ruling if circumstances change as further facts are developed. The single judge can use a firm hand without fear of strait-jacketing the proceedings, whereas absent a onejudge system, he might be fearful that another judge would be more reluctant to upset or modify his ruling in light of changed circumstances as the litigation progresses. 
The approach to the discovery problem must, therefore, be a practical one. No set of rules can be applied to every case indiscriminately. The devices suggested by the Committee will be helpful in most cases, although, indiscriminately used, they might be harmful in others. They should be used, with discretion, and only where needed.

\section{Limited Period of Relevant Inquiry}

Where any party to a proceeding under the antitrust laws offers proof covering more than a reasonable number of years in the past, stern measures may be necessary to keep the proceeding from getting completely out of hand. The landmark decision dealing with this problem is United States $v$. Oregon State Medical Soc'y. ${ }^{51}$ Drawing heavily on the opinion in that case, the Committee sets forth a number of guides to be followed in limiting proof and, in particular, in fixing a cut-off date for proof in cases where that appears necessary. ${ }^{52}$

Separate Trials

Like the problem of limiting proof, the final matter dealt with under this heading, that of separate trials, is essentially a question of practical considerations. The Committee recommends separate trials of (1) the issues of liability and damages in nonjury ${ }^{\tilde{5} 3}$ treble damage cases, (2) the validity of patents where that is an issue, ${ }^{54}$ and (3) the question of relief where the Government seeks "dissolution, divestiture or other complex relief posing knotty economic problems." The Committee suggests also the possibility that in rare instances it may be convenient to proceed from issue to issue, hearing all of the evidence from all parties on each issue before proceeding to the next. Of course, this procedure can be used only with the consent of all the defendants because it deprives them of the opportunity to make a motion to dismiss at the close of the plaintiff's case. ${ }^{55}$

51. 343 U.S. 326 (1952).

52. REPORT at 364.

53. There is no reason why this recommendation cannot be applied to jury cases as well, under an arrangement whereby the same jury will try the question of damages immediately following a verdict for the plaintiff. This device has been used in the Eastern District of Pennsylvania. E.g., Harrison v. Paramount Pictures, Inc., Civil No. 12,203, E.D. Pa., where the verdict on the liability issue was for the defendants, and the parties and the court were thus saved many days of trial time which would have been involved in presentation of evidence on damages. Power to order separate trials is given by FED. R. Crv. P. 42(b); see 5 Moore, FEDERAI Practice 1217 (2d ed. 1951).

54. We do not share the view expressed by one member of the Committee (REPORT at 365) that this recommendation will lead to trial of the patent issue first. The Committee's recommendation did not deal with the order of trial, a question which must necessarily be decided on an ad hoc basis, according to the practical situation existing in the specific case. The possibility that the patent licensee will be worn down by expensive and protracted patent litigation before he has opportunity to prove his antitrust claim is one which, if present, should be considered by the court in making its decision.

55. Ibid. 
The Committee recommends devices such as these in the hope that their intelligent use will partially alleviate the burdens of protracted litigation both on the courts and on the parties. The Committee rejected, as inconsistent with the function of our judicial process, the suggestion that the courts should be provided with an independent staff of economic experts, with its implicit premise that judges are not adequately equipped to consider the complex economic problem presented by some Sherman Act cases..$^{56}$

\section{Compliance with and Modification of Antitrust Judgments}

The Committee's discussion and recommendations on this subject relate primarily to internal administration of the Antitrust Division in so far as enforcement of and changes in decrees are concerned.

Of primary importance to counsel representing private parties is an understanding of the problem of future modification of an antitrust decree. We have referred earlier to the matter of modifying consent decrees; ${ }^{57}$ the situation is the same where a litigated decree is involved.

It is not surprising that two of the Committee's recommendations in this sphere were unanimous: (1) that the Department conduct regular studies respecting outstanding decrees to ascertain whether they have been effective for the purposes intended, primarily to restore competition, and (2) that the Department consent to modification of decrees where defendants demonstrate a change in circumstance. While the Division has always been reluctant to agree to any significant modification of decrees, and the courts have likewise been disinclined to order such changes, it would seem that with 378 decrees having been entered since $1890,{ }^{58}$ a change in attitude is indicated. The progress of the law of antitrust and changes in circumstance occur too often and too rapidly to permit a "hands off" attitude when a defendant can establish that a decree has proved too broad or has produced inequality in competition.

Finally, the Committee notes the Department's use, where appropriate, of provisions which expressly expire after a stated period and of provisions under which defendants may, after a stated period, show that conditions have changed so that relief originally necessary to dissipate the effects of past unlawful practices is no longer required. ${ }^{69}$ Particularly in the face of the present attitude of the Division and courts

56. Id. at 366 .

57. See p. 295 supra.

58. REPORT at 366.

59. Id. at 367 . 
concerning modification of decrees in antitrust suits brought by the Government, private counsel should be alert to the availability of such devices and urge them upon the Division in consent decrees and upon the courts where decrees in adversary proceedings are to be entered.

\section{Advance Clearance and Releases}

Lawyers advising clients on the antitrust implications of a contemplated course of action would find it comforting if they could obtain advisory opinions from the Department of Justice. However, the Department takes the position that it has no authority to issue advisory opinions. The most that the Department will do is give clearance for a particular merger as not violative of section 7 of the Clayton Act, ${ }^{60}$ and, under the Sherman Act, make a binding commitment not to resort to criminal action in any case where it has issued a so-called "railroad release." ${ }^{61}$ Relatively few requests for railroad releases are granted. In such cases, the Department requires that there be a full disclosure of all information, that the plan be prospective rather than already in operation and, of course, that the facts demonstrate that both the plan and its contemplated operation are not likely to be in conflict with the antitrust laws.

The Committee recognized that the generality of the antitrust laws, coupled with the conflicting and confusing court decisions in this field, fails to provide the businessman with reasonably ascertainable standards by which he can determine the legality of a contemplated course of conduct. Attempts at compliance are hazardous, especially since the Sherman Act is a criminal statute.

In light of this problem, the Committee considered suggestions that the Antitrust Division be authorized to issue rules and regulations of general application and advisory opinions on particular states of fact, as well as the proposal that the Federal Trade Commission be authorized to conduct conferences, participated in by the Antitrust Division and other interested parties, where clearance is sought as to industry-wide problems.

The Committee rejected these suggestions on several grounds. It was felt that the Department, as a prosecuting agency, should not be expected to issue advance clearances. Further, it was considered that

60. FTC clearance for a merger can likewise be obtained, but this is a limited clearance on a staff, rather than Commission level. Rules 61-63 of the Commission's General Procedures provide that private parties may obtain "staff views" as to ". . . whether or not consummation of the merger would be likely to result in further action by the Commission." 20 FED. REG. 3057 (May 6, 1955).

61. REPORT at 367. 
any such clearance would necessarily be of limited value, inevitably subject to revision in light of subsequent factual developments. Finally, the Committee recognized that there might be danger in broad advisory decisions, which could affect the economic life of an industry, made without the benefit of a set of investigated facts. ${ }^{62}$ As did the Committee, lawyers representing private clients must accept as inevitable a degree of uncertainty in the antitrust field and the unavailability and undesirability of iron-clad advisory opinions.

However, the Committee expressly recognized also the value of informal discussions of problems between private counsel and the Antitrust Division, a procedure which, as we have previously indicated, we believe attorneys should eagerly seek and enthusiastically welcome. First of all, such discussion gives opportunity to even the most experienced antitrust lawyer to obtain the prosecutor's viewpoint, often a valuable ingredient for the amalgam of judgment which must be brought to bear in rendering advice on any serious antitrust problem. Secondly, if and when an issue later arises, although private counsel cannot hold a prosecutor to an opinion previously expressed, the fact of such expression of opinion is bound to have effect upon later discussions between the parties and with the court to the extent reference thereto is proper under all the circumstances.

\section{The Federal Trade Commission}

Of the multitude of problems confronting the FTC, many of which are similar to those facing the Department of Justice, the Report considers three specific matters only: the Trade Practice Conference, the FTC's informal settlement procedures and problems of enforcement of Commission orders and penalties for their violation. The Report also considers problems arising out of the related jurisdiction of the FTC and the Department of Justice. Much of what is said on these questions goes to matters of internal administration as distinguished from those having a more direct effect on private parties. The Committee's discussion will provide valuable background reading for anyone undertaking to represent a client before the Commission, but especially in light of the fact that, as the Report notes, a number of existing Commission procedures were in the process of study and revision when the Report was written, new rules covering practice before the Commission having since been issued, ${ }^{63}$ any expansion by us on what is said in the Report itself would unduly lengthen this article.

62. Id. at 368 . 1955).

63. 20 FEd. Reg. 3055 (May 6, 1955), as amended, 20 FEd. REg. 3303 (May 14, 


\section{Private Antitrust SuIts}

As the Committee characterized it, "the private antitrust suit blends antitrust policy with private compensatory law : on the one hand, as one Clayton Act proponent put it, such suits aim to enlist "the business public . . . as allies of the Government in enforcing the antitrust laws;' the means chosen, on the other hand, is to give 'the injured party ample recompense for the wrong suffered' by allowing threefold recovery of damages." 84

In terms of the likelihood of contact with litigation involving the antitrust laws, the private suit, whether for treble damages or injunctive relief, or both, is of paramount importance to the practicing lawyer representing private clients. This fact is underscored by the mushrooming of private suits in recent years, as noted in the Report. During the first 50 years that the Sherman Act was in effect, there were only 175 private actions, in 13 of which the plaintiff succeeded. Following World War II, however, there was a great increase. From June, 1947, to June, 1951 , the number of private antitrust suits pending in the district courts grew from 118 to 367 , and recoveries increased almost correspondingly. Since 1951, the growth has been even more rapid. ${ }^{65}$

Nearly all of the Report is valuable and useful in connection with the private suit because its substantive teachings are applicable there as well as to the government proceeding. Furthermore, as we have noted, some of the matters treated earlier in the Administration and Enforcement Chapter are likewise of equal applicability to the private suit. As relating directly to the private suit, the Committee singled out for treatment only three specific matters. One of the three, the recommendation that the United States be given a right to sue for single damages to its proprietary interests, has already been mentioned. ${ }^{68}$

\section{Treble Damages}

The next and by far the most controversial is the proposal to remove the present mandatory treble damage requirement and substitute discretion in the trial judge to double or triple the damage award. ${ }^{67}$

The Committee's endorsement of discretionary trebling rests primarily on the view that the generality and the dynamic nature of the antitrust laws present a serious danger of unwitting violation. The unwitting violator should, in fairness, be accorded treatment different from that meted out to the deliberate lawbreaker, just as the Department of

64. REPORT at 378. (Footnotes omitted.)

65. Ibid.

66. See p. 286 supra.

67. REPORT at 378. 
Justice makes a conscious choice between the punitive criminal action and the purely remedial civil action for injunctive relief. The Committee felt that discretionary trebling would not weaken the deterrent effect of the damage suit because the deliberate violator could not expect any benefit from the court's discretion. Similarly, the Committee felt that there would be no curtailment of the incentive to sue; the development of substantive and procedural law, largely favorable to the plaintiff's position, and the statutory provision for attorneys' fees offer ample incentive. This is especially true in view of the fact that it has now been established that the trebled recovery is taxable as ordinary income, thus materially decreasing the amount which a successful plaintiff can net. $^{68}$ Finally, liberal rules for measuring damages give reasonable assurance that a successful plaintiff will obtain adequate compensation for his loss. ${ }^{69}$

In any event, it does not seem unfair or illogical to reserve the penalty of triple damages for the deliberate violator-in no case, however, depriving an injured plaintiff of at least full recompense for his damage plus his attorneys' fees and costs.

Rejecting the counter-arguments that good faith, good intentions and even admitted social gains afford no defense to a charge of violation and therefore should not determine treble damages and that, since the criminal penalty is light, ${ }^{70}$ there should be no weakening of the treble damage threat even though the trebling of damages may in some cases work an injustice, a majority of the Committee recommended discretionary trebling. Drawing on the precedents furnished by other federal statutes, the Committee recommended that the discretion be reposed in the trial judge and rejected as impracticable the notion of spelling out statutory standards to guide the judge's discretion. ${ }^{71}$

Several members of the Committee dissented from this recommendation, arguing that discretionary trebling should be limited to Clayton Act violations but that mandatory trebling should remain for ". . . major Sherman Act offenses, normally involving a substantial public interest. . . ."72 We agree with the majority's rejection of this refinement because we believe that the basic consideration of eliminating unfairness to unknowing transgressors applies with equal force in all antitrust cases, whether under the Sherman Act or the Clayton Act.

68. Commissioner v. Glenshaw Glass Co., 348 U.S. 426 (1955). A bill pending in the present Congress would change this result. H.R. 7737, 84th Cong., 1st Sess. (1955).

69. REPORT at 378-79.

70. This is no longer true in view of the increase in the maximum fine, from $\$ 5,000$ to $\$ 50,000$. See note 23 supra.

71. REPORT at 380.

72. Id. at 379 . 
The same consideration answers the charge of another dissenting member that ". . . the Committee made no finding of any adverse effect of the mandatory treble damage provision on the public interest." 73 We believe there is sufficient adverse effect on the public interest in any law which punishes alike the witting and the unwitting violator, when no such procedure is necessary to compensate adequately the injured party for any damage he may have suffered or effectively to enforce the antitrust laws.

An attempt to implement the Committee's recommendation is made in a bill introduced in the present Congress, ${ }^{74}$ which, as presently amended, contains a proviso to the effect that treble damages are required if the violation is "willful." This provision would, of course, raise all of the difficulties inherent in the concept of willfulness and would pose the problem whether the existence of willfulness is to be determined by the judge or the jury. The Committee's recommendation for an unfettered discretion in the trial judge would be much simpler to administer and is in line with other federal legislation. In addition, it would remove the present vexing problems arising out of the question whether the jury may be told that its award will be trebled. It has been held that it is not reversible error so to advise the jury, ${ }^{75}$ but not all trial judges will advise the jury that trebling will occur or permit counsel to do so. The question whether such refusal is reversible error has not yet been decided.

\section{Statute of Limitations}

In its next recommendation, the Committee was unanimous in asking for the adoption of a four-year federal statute of limitations to govern all private antitrust suits. This recommendation has already been adopted and will become effective January 7, 1956. ${ }^{76}$ Under prior law, there being no federal provision, the applicable statute of limitations had to be supplied by state law, an approach which, as the Committee noted, ". . . produced more questions than answers." 77 An inequitable and illogical consequence of reference to state law was the fact that applicable periods of limitation varied from periods as short as one year to others as long as twenty years. ${ }^{78}$

73. $I d$. at 380 .

74. H.R. 6875, 84th Cong., 1st Sess. (1955).

75. Bordonaro Bros. Theatres, Inc. v. Paramount Pictures, Inc., 203 F.2d 676 (2d Cir. 1953).

76. Pub. L. No. 137, 84th Cong., 1st Sess. (July 7, 1955).

77. REPORT at 381.

78. Id. at $383-84$ n. 80 . 
The Committee's recommendation for a four-year statute of limitations dealt also with related questions arising under the tolling provision in section 5 of the Clayton Act, suspending private statutes of limitations during the pendency of a government suit. Recognizing injustices which have occurred where government proceedings have been pending for many years, the Committee suggested a redrafting of section 5 so as to produce a more careful definition of its operation and to make provisions that: (1) any person relying on suspension of the statute of limitations should be barred after one year from the end of the suspension period; and (2) the damages to be recovered by any such person should be limited to any consecutive four-year period not otherwise barred. ${ }^{79}$

Only one of these suggestions found its way into the legislation. As passed, the amendment to section 5 of the Clayton Act changes the original provision by specifying that the suspension shall be during the pendency of the government proceeding and for one year thereafter, and by adding a proviso that, when the running of the statute of limitations is suspended in respect to any cause of action, enforcement of the cause of action is barred unless an action is commenced during the suspension period or within four years after accrual of the cause of action.

The statute of limitations, as it has been adopted, follows the Committee's recommendation that the statute run from accrual of the cause of action. ${ }^{80}$ This is the typical provision found in most statutes of limitation. ${ }^{81}$ Some of the earlier legislative proposals on this subject had included a provision that the period of limitations should be suspended, in conspiracy cases, until the plaintiff had discovered the facts upon which he relied for proof of the conspiracy. ${ }^{82}$ Of course, a statute phrased in such form would be practically no limitation at all, especially if it meant, as its language could have been interpreted to mean, that the statute would not run until the plaintiff had discovered all of the facts upon which he wished to rely. ${ }^{\mathrm{s}}$ The rejection of any provision

79. Id. at $384-85$.

80. Id. at 383.

81. See Developments in the Lare-Statutes of Limitations, 63 Harv. L. Rev. 1177, 1200 (1950); Uniforar Statute of Limitations ACr $\$ 2$.

82. S. 1910, 81st Cong., 1st Sess. (1949) ; H.R. 7905, 81st Cong., 2d Sess. (1950). The provision in S. 1910 allowed the plaintiff, in a case of alleged conspiracy, six years ". . after the discovery by the plaintiff of the facts upon which he relies for proof of the existence of such conspiracy, if the plaintiff has exercised due diligence in seeking to discover such facts."

83. For a thorough analysis of the undesirability of a "discovery" provision and the lack of necessity for it, see Hearings Before the Subcommittee on H.R. 7905 of the House Committee on the Judiciary, 81st Cong., 2d Sess. 20-22 (1950). 
such as this was, we think, a wise choice on the part of the Committee and on the part of the Congress in implementing the Committee's recommendation.

\section{Conclusion}

Steady progress is being made in the intelligent and effective administration and enforcement of the antitrust laws. Much, however, remains to be done, and the officials in charge of the enforcement agencies of the Government would, we believe, be the first to concede this.

Chapter VIII of the Report, which we have discussed, makes numerous suggestions for improvement of internal procedures, for legislative change and for somewhat altered approaches by the courts. In our judgment, these will, if adopted, contribute substantially to the more effective administration and enforcement of the antitrust laws and upon bases more equitable and logical than at present.

Some of the more drastic recommendations made principally by one dissenting member of the Committee would appear to be unnecessary and might well become instruments of oppression; others should at least await a trial of the more moderate and, we believe, more realistic recommendations of the Report. 
.

x 

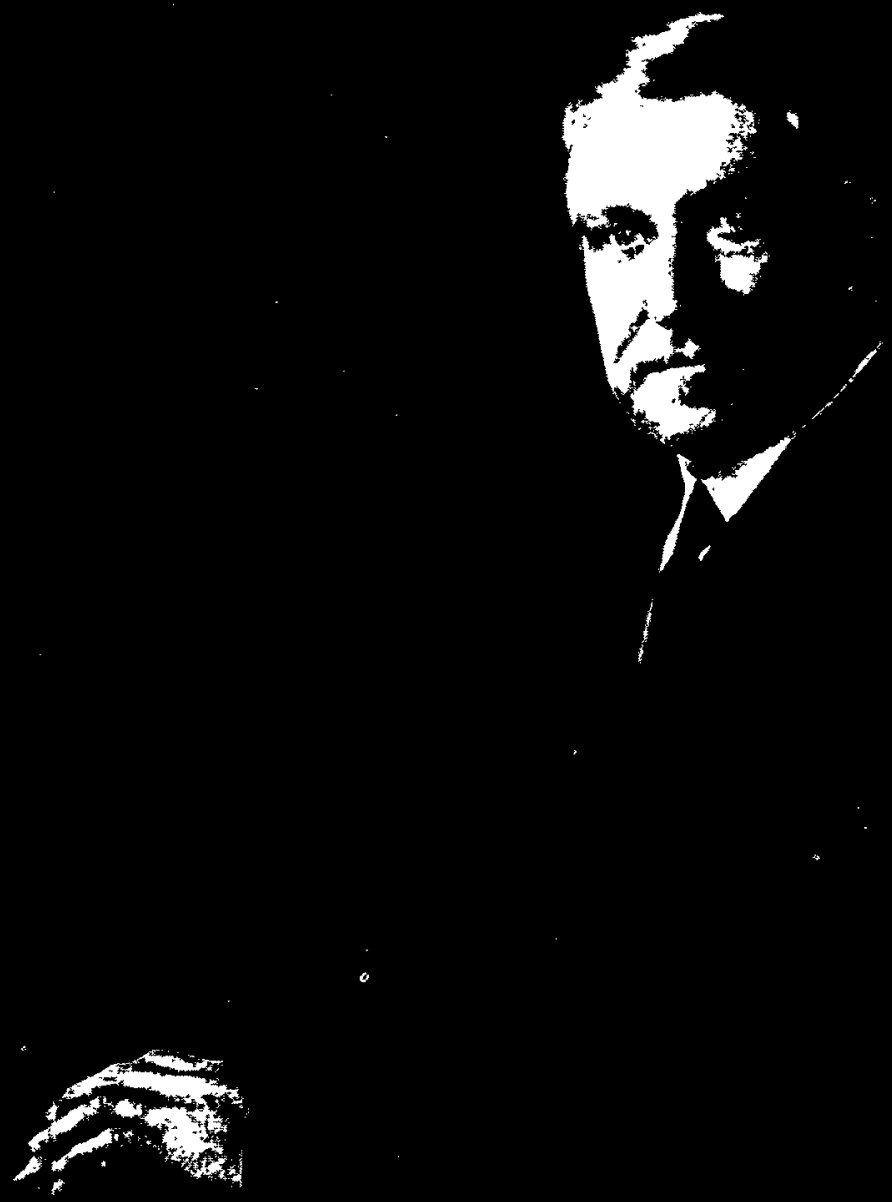